\title{
Pembelajaran Berbasis Guided Inquiry Untuk Meningkatkan Literasi Sains Siswa Kelas X MIPA Pada Materi Larutan Elektrolit Dan Nonelektrolit
}

\author{
MIOKTI YESSI \\ SMA Negeri 7 Palangka Raya, Provinsi Kalimantan Tengah, Indonesia \\ Email: yessikimia86@gmail.com
}

\begin{abstract}
Abstrak: Penelitian ini bertujuan untuk menganalisis kemampuan literasi sains siswa kelas $\mathrm{X}$ program IPA melalui model pembelajaran inkuiri terbimbing (guided inquiry) pada materi larutan elektrolit dan non elektrolit, efektivitas pembelajaran dan peningkatan penguasaan konsep siswa. Penelitian dilakukan di SMA Negeri 7 Palangka Raya Tahun Pelajaran 2018/2019. Penelitian ini menggunakan desain one group pretest-postest. Pengumpulan data dilakukan dengan metode tes, dan observasi.. Hasil penelitian menunjukkan bahwa rerata kemampuan literasi berada pada kategori baik dan terjadi peningkatan kemampuan literasi sains siswa dengan gain score 0,84 kategori tinggi, dengan rata-rata nilai posttest siswa 92,69 dengan tingkat ketuntasan belajar siswa $100 \%$. Hasil penelitian disimpulkan bahwa setelah penerapan model pembelajaran berbasis guided inquiry efektif meningkatkan kemampuan literasi sains siswa dengan kategori tinggi.
\end{abstract}

\section{Kata Kunci: elektrolit, larutan, nonelektrolit}

\section{Pendahuluan}

Pembelajaran ilmu kimia merupakan bagian dari pembelajaran ilmu Pengetahuan Alam (IPA) yang merupakan konsep-konsep yang berjenjang, berkembang dari konsep-konsep yang sederhana menuju konsep-konsep yang lebih kompleks. Pembelajaran kimia di SMA merupakan kerangka dasar proses pemahaman siswa tentang ilmu kimia.

Sains berkaitan dengan cara mencari tahu tentang alam secara sistematis, kumpulan pengetahuan yang berupa fakta-fakta, konsep-konsep atau prinsipprinsip serta merupakan suatu proses penemuan (Pusat Kurikulum, 2003:6-7). Kimia merupakan salah satu rumpun sains yang berkembang dan diperoleh melalui pengumpulan data dengan eksperimen terhadap gejala alam maupun karakteristik alam sekitar yang dilakukan secara sistematis. Melalui pendidikan sains, khususnya kimia diharapkan menjadi wadah bagi siswa untuk lebih memahami, mengeksplorasi pengetahuan dan memperoleh pemahaman yang bermakna tentang alam sekitar beserta fenomena yang terjadi serta dapat menerapkannya di dalam kehidupan sehari-hari. Hal ini menempatkan proses pembelajaran menduduki posisi yang sama pentingnya dengan hasil pembelajaran yang akan dicapai oleh siswa (Trianto, 2007:103).

Kurikulum 2013 menyajikan beberapa materi pembelajaran sains khususnya kimia. Materi pembelajaran itu dijabarkan melalui Kompetensi Inti (KI) dan Kompetensi Dasar (KD) yang kemudian dijabarkan menjadi beberapa konsep. Banyaknya konsep kimia yang dipelajari dan diserap oleh siswa dalam waktu yang terbatas menyebabkan siswa sulit menguasai konsep kimia ((Napsin Palisoa, 2008:31). Pembelajaran kimia yang kurang mengaitkan dengan konteks kehidupan sehari-hari juga dapat menyebabkan pembelajaran tersebut kurang 
bermakna. Hal ini sejalan dengan yang diungkapkan oleh M. Pranjoto Utomo (2011:3), kesulitan mempelajari ilmu kimia terkait dengan karakteristik ilmu kimia itu sendiri, yaitu bersifat abstrak. Untuk mengatasi hal tersebut dalam mempelajari ilmu kimia perlu penyederhanaan dari ilmu kimia yang sebenarnya, bahan pelajaran kimia disusun dari konsep yang lebih sederhana menuju yang sukar, dan bahan pelajaran kimia tidak hanya menyelesaikan soal-soal. Dengan demikian dapat menyiapkan peserta didik yang mampu berpikir kritis, logis, kreatif sehingga mampu menjawab persoalan yang terkait dengan kehidupan sehariannya. Hal ini menjadikan kimia menjadi lebih mudah dipahami dan diaplikasikan sehingga lebih bermakna bagi kehidupan.

Pembelajaran yang bermakna dapat terlaksana dengan baik apabila siswa dapat menghubungkan antara pengetahuan yang telah dimiliki sebelumnya dengan pengetahuan yang baru. Sehingga apa yang didapatkan tidak sekedar hanya konsep belaka tetapi menjadi modal siswa dalam meningkatkan kemampuan intelektualnya termasuk didalamnya adalah berpikir tingkat tinggi. Hal ini sejalan dengan pendapat Piaget bahwa pengetahuan merupakan hasil proses berpikir manusia (organizing and adapting) yang dikonstruksi dari proses pengalamannya secara terus-menerus dan setiap kali dapat terjadi rekonstruksi karena adanya pemahaman baru yang diperoleh melalui proses adaptasi belajar (Udin S. Winataputra, dkk, 2007).

Kebermaknaan dalam pembelajaran sains bagi siswa dapat diperoleh jika siswa memiliki kemampuan literasi sains yang baik. Literasi sains menurut PISA OECD (Programme for International Student Assessment-Organization for Economic Cooperation and Development, 2004:26), didefinisikan sebagai berikut "the capacity to use scientific knowledge, to identify questions and to draw evidence-based conclusions in order to understand and help make decisions about the natural world and the changes made to it through human activity". Definisi literasi sains ini memandang literasi sains bersifat multidimensional dalam aspek pengukurannya, yaitu konten sains, proses sains, dan konteks aplikasi sains. Dengan demikian siswa mampu menggunakan pengetahuan sains dan dapat menerapkannya dalam memecahkan persoalan keseharian yang berkaitan dengan materi yang dipelajari.

Berdasarkan hasil studi PISA terhadap literasi sains siswa yang dilakukan setiap tiga tahun sekali, terungkap bahwa literasi sains siswa Indonesia dari berbagai tahun disajikan dalam Tabel 1 .

Tabel 1. Data Skor Literasi Sains Siswa Indonesia dari Tahun Ke Tahun

\begin{tabular}{lcccccc}
\hline Tahun & $\mathbf{2 0 0 0}$ & $\mathbf{2 0 0 3}$ & $\mathbf{2 0 0 6}$ & $\mathbf{2 0 0 9}$ & $\mathbf{2 0 1 2}$ & $\mathbf{2 0 1 5}$ \\
\hline Skor & 393 & 395 & 393 & 383 & 382 & 403 \\
Peringkat & $38 / 41$ & $38 / 40$ & $50 / 57$ & $60 / 65$ & $64 / 65$ & $62 / 70$ \\
\hline
\end{tabular}

(Sumber: OECD, 2015)

Berdasarkan Tabel 1, terlihat bahwa selama 15 tahun penilaian yang dilakukan oleh PISA terhadap siswa Indonesia yaitu dari 2000 hingga 2012 justru mengalami penurunan sebanyak 11 poin dan terjadi peningkatan pada tahun 2015 . Hal ini menunjukkan bahwa pembelajaran sains di Indonesia umumnya masih didominasi oleh praktik yang menganggap bahwa pengetahuan sains itu berupa seperangkat fakta yang harus dihafal. Hasil capaian tersebut mengungkapkan 
bahwa rata-rata kemampuan sains peserta didik Indonesia hanya mampu mengenali fakta dasar, mereka belum mampu untuk mengkomunikasikan dan mengaitkan kemampuan tersebut dengan berbagai topik sains, apalagi sampai dengan menerapkan konsep-konsep. Uus Toharudin, Sri Hendrawati \& Andrian Rustaman (2011:16) berpendapat bahwa hasil ini memiliki perbedaan yang sangat signifikan dengan skor rata-rata internasional yang mencapai 500. Dengan pencapaian tersebut, kemampuan rata-rata peserta didik Indonesia baru sampai pada kemampuan mengenali sejumlah fakta dasar, tetapi belum mampu mengkomunikasikan dan mengaitkan kemampuan itu dengan berbagai topik sains.

Badan Standar Nasional Pendidikan (BSNP) (2006), mengungkapkan bahwa Ilmu Pengetahuan Alam (IPA) bukan hanya merupakan penguasaan kumpulan pengetahuan yang berupa fakta-fakta, konsep-konsep, atau prinsipprinsip saja, tetapi juga merupakan proses penemuan, yaitu proses mencari tahu tentang fenomena alam secara sistematis. Pendidikan IPA diharapkan dapat menjadi wahana bagi peserta didik untuk mempelajari diri sendiri dan alam sekitar, serta prospek pengembangan lebih lanjut dalam penerapan di dalam kehidupan sehari-hari. Berdasarkan uraian tersebut, pembelajaran sains tidak hanya terfokus pada penguasaan konten sains saja, tetapi juga harus melibatkan penguasaan konteks dan proses sains. Pembelajaran bermutu sesuai dengan kurikulum yang diharapkan, ditunjang dengan adanya sumber belajar yang memuat tujuan kurikulum, salah satunya penguasaan literasi sains baik penguasaan konten, konteks, maupun proses sains.

Hal tersebut menunjukkan bahwa siswa mengalami kesulitan dalam mendapatkan makna dan menggunakan sains untuk memecahkan berbagai permasalahan yang terjadi dalam kehidupan sehari-hari yang sebenarnya membutuhkan pemahaman sains yang baik. Untuk melihat kemampuan literasi sains siswa maka dilakukan pemberian soal literasi sains pada materi Larutan Elektrolit dan Non Elektrolit yang diujikan kepada siswa kelas XII MIPA SMA Negeri 7 Palangka Raya. Rekapitulasi hasil analisis terhadap jawaban siswa disajikan pada Tabel 2.

Tabel 2. Persentase Hasil Analisis Jawaban Soal Uraian perIndikator Soal (Pra Riset) Siswa Kelas XII IPA SMA Negeri 7 Palangka Raya

\begin{tabular}{|c|c|c|}
\hline No. & Indikator & Persentase \\
\hline 1. & Menuliskan pengertian larutan elektrolit & $100 \%$ \\
\hline 2. & Menuliskan pengertian larutan non elektrolit & $100 \%$ \\
\hline 3. & $\begin{array}{l}\text { Menjelaskan penyebab timbulnya hantaran arus listrik pada } \\
\text { larutan elektrolit }\end{array}$ & $80,95 \%$ \\
\hline 4. & $\begin{array}{l}\text { Menjelaskan penyebab tidak timbulnya hantaran arus listrik } \\
\text { pada larutan non elektrolit }\end{array}$ & $76,19 \%$ \\
\hline 5 . & Mengelompokkan senyawa yang termasuk larutan elektrolit & $90,48 \%$ \\
\hline 6. & $\begin{array}{l}\text { Mengelompokkan senyawa yang termasuk larutan non } \\
\text { elektrolit }\end{array}$ & $95,24 \%$ \\
\hline 7. & $\begin{array}{l}\text { Menjelaskan penyebab daya hantar listrik berdasarkan reaksi } \\
\text { ionisasi dari beberapa senyawa yang diberikan }\end{array}$ & $61,90 \%$ \\
\hline 8. & $\begin{array}{l}\text { Menjelaskan penyebab tidak adanya daya hantar listrik dari } \\
\text { beberapa senyawa yang diberikan }\end{array}$ & $47,62 \%$ \\
\hline 9. & Menganalisis pengaruh larutan isotonik terhadap tubuh & $38,09 \%$ \\
\hline
\end{tabular}




\begin{tabular}{llc}
\hline No. & \multicolumn{1}{c}{ Indikator } & Persentase \\
\hline 10. & $\begin{array}{l}\text { Membedakan fungsi larutan elektrolit dan non elektrolit bagi } \\
\text { tubuh }\end{array}$ & $42,86 \%$ \\
\hline
\end{tabular}

Berdasarkan data Tabel 2, dapat disimpulkan bahwa sebagian besar siswa cenderung hanya menghafal materi yang diberikan dan dalam pembelajaran tidak dikaitkan antara materi dengan aplikasi dalam kehidupan sehari-hari. Hal ini terlihat dari keseluruhan siswa dapat menjawab soal tentang definisi dan mengelompokkan larutan elektrolit dan non elektrolit. Namun siswa mengalami kesulitan dalam menjelaskan penyebab daya hantar listrik berdasarkan reaksi ionisasinya serta dalam memecahkan soal yang bersifat kontekstual. Berdasarkan berbagai permasalahan yang telah dipaparkan maka perlu adanya pembelajaran yang dapat mengembangkan kemampuan literasi sains siswa sehingga pembelajaran menjadi lebih bermakna. Pembelajaran literasi sains merupakan pembelajaran yang relevan untuk mengembangkan kemampuan literasi sains yang sesuai dengan proses dan produk kehidupan sehari-hari dalam masyarakat.

Pembelajaran ini memasukkan isu-isu sosial yang memerlukan komponen konsep sains dalam pengambilan keputusan untuk pemecahan masalah dan membantu siswa dalam hal penyelesaian masalah (Jack Holbrook dan Miia Rannikmae, 2009). Tahapan pembelajaran literasi sains merupakan pembelajaran yang menerapkan tahapan pembelajaran literasi sains menurut Peter Nentwig, et al (dalam Peter Nentwig and David Waddington, 2005:162) dengan penambahan tahap pengambilan keputusan (decision making) berdasarkan Jack Holbrook (2011:19), yaitu meliputi tahap kontak, tahap kuriositi, tahap elaborasi, tahap pengambilan keputusan dan tahap rekontekstualisasi. Tahap kontak dikemukakan isu-isu yang terjadi di masyarakat yang dapat bersumber dari artikel koran, klipTV, gambar, dan sebagainya demi membangun minat belajar siswa. Selanjutnya pada tahap kuriositi akan dikemukakan pertanyaan-pertanyaan terkait isu dan materi yang berkaitan untuk mengundang rasa penasaran siswa. Tahap elaborasi dilakukan pembentukan dan pemantapan konsep. Kemudian pada tahap pengambilan keputusan guru membimbing siswa untuk melakukan peninjauan kembali isu-isu di awal dan menuangkan ide sains baru yang tumbuh untuk menjawab pertanyaan dari isu tersebut. Tahap rekontekstualisasi, dimana guru membimbing siswa untuk mengambil konsep dasar dari materi dan mengaplikasikannya pada konteks yang berbeda yang memerlukan pengetahuan konsep yang sama untuk pemecahannya.

Pembelajaran literasi sains salah satunya dapat dilakukan melalui praktikum. Praktikum yang dilakukan berupa merancang dan menggunakan bahan dalam kehidupan sehari-hari sehingga siswa dapat mengaitkannya dengan konsep yang diperoleh dari hasil percobaan. Hal ini diperkuat berdasarkan Permendiknas No 23 tahun 2006 tentang Standar Kompetensi Lulusan, salah satu butir menyebutkan bahwa pembelajaran kimia seharusnya dapat membuat siswa melakukan percobaan, dua diantaranya yaitu merancang dan merakit instrumen (Permendiknas, 2006). Menurut Woolnough dan Allsop (dalam Tri Astuti, 2015) praktikum bertujuan untuk: a) membangkitkan keingintahuan, b) mempelajari teknik dan keterampilan, c) mempelajari proses dalam ilmu pengetahuan dan d) mendukung teori dan konsep dalam buku pelajaran. Dengan melakukan praktikum yang merancang instrumen sendiri dan menggunakan bahan dalam kehidupan 
sehari-hari maka dapat membuat siswa merasa kimia sangat dekat dan berkaitan dengan kehidupan sehari-hari.

Literasi adalah salah satu keterampilan abad 21 yang harus dimiliki oleh setiap siswa untuk dapat menghadapi persaingan di era revolusi industri 4.0. Literasi kimia merupakan pemahaman tentang sifat partikel materi, reaksi kimia, hukum dan teori kimia, dan aplikasi kimia umum dalam kehidupan sehari-hari. Menurut Shwartz, et al., (2006) seseorang yang memiliki kemampuan literasi kimia yang baik harus memahami konsep dasar sains/kimia. Menurut PISA literasi sains merupakan kemampuan untuk menghubungkan isu-isu yang berkaitan dengan sains dan gagasan-gagasan sains, sebagai warganegara yang reflektif (OECD, 2016). Literasi sains PISA dibagi menjadi 4 aspek yang saling terkait, yaitu aspkek konten, konteks, kompetensi, dan sikap sains (OECD, 2014; OECD, 2016). Pentingnya literasi kimia berhubungan dengan bagaimana siswa mampu menghargai alam dengan memanfaatkan sains dan teknologi yang telah dikuasainya (Nisa, et al., 2015). Rendahnya kemampuan literasi sains/kimia peserta didik terbukti dari hasil survey Programme for Internasional Students Assesment (PISA) bahwa tahun 2000 sampai 2015 menunjukkan bahwa tingkat pencapaian literasi sains peserta didik Indonesia masih dalam level rendah.

Salah satu model pembelajaran yang dapat digunakan untuk memfasilitasi peserta didik dalam meningkatkan literasi kimia peserta didik yaitu model pembelajaran inkuiri. Adapun sintak model pembelajaran inkuiri terbimbing yang digunakan adalah orientasi, merumuskan masalah, merumuskan hipotesis, mengumpulkan data, menguji hipotesis, dan merumuskan kesimpulan (Sanjaya, 2012: 200). Pembelajaran berbasis inkuiri merupakan pembelajaran yang berpusat pada peserta didik (Suyanti, 2010). Tujuan dasar inkuiri yaitu untuk memberi peserta didik pengalaman berinisiatif untuk menentukan masalah sosial, kemudian mendiskusikan dan/atau merumuskan dan merekomendasikan sebuah kebijakan untuk menyelesaikan masalah tersebut. McConney, et al., (2014) mengungkapkan bahwa pembelajaran inkuiri yang berorientasi pada penyelidikan memungkinkan siswa memiliki kemampuan literasi sains yang lebih tinggi dan berpengaruh positif terhadap pemahaman dan pengamalam sains. Penelitian terdahulu juga mengungkapkan bahwa pembelajaran berbasis inkuiri terbimbing lebih efektif dalam meningkatkan literasi sains peserta didik (Puspitasari, 2015) dan dapat meningkatkan hasil prestasi belajar peserta didik (Murniningsih, 2016).

Rumusan masalah dalam penelitian ini yaitu bagaimana kemampuan literasi kimia peserta didik melalui penerapan model pembelajaran inkuiri? Penelitian ini bertujuan untuk menganalisis kemampuan literasi kimia siswa pada aspek konten, konteks, kompetensi, dan sikap terhadap kimia.

\section{Metodologi Penelitian}

Penelitian ini merupakan penelitian eksperimen semu menggunakan One Group Pretest-Posttest Design. Tempat penelitian dilakukan di SMA yang berada di Kota Palangka Raya pada siswa kelas X MIPA semester II Tahun Pelajaran 2018/2019. Guided Inquiry diterapkan pada materi larutan elektrolit dan nonelektrolit, yang tercakup dalam Kompetensi Dasar (KD) 3.8 yaitu menganalisis sifat larutan berdasarkan daya hantar listriknya. Pengumpulan data menggunakan instrumen soal tes bentuk uraian, observasi dan wawancara tidak terstruktur. Soal tes berisi item-item soal yang bertujuan untuk mengukur 
peningkatan kemampuan literasi sains siswa dan klasifikasi tingkat penguasan konsep siswa berdasarkan ketuntasan belajar siswa pada materi larutan elektrolit dan nonelektrolit baik sebelum (pre-test) atau setelah implementasi pembelajaran (post-test). Hasil pre-test dan post-test diolah dan dianalisis untuk mengetahui peningkatan penguasaan konsep dan peningkatan kemampuan literasi sains siswa. Peningkatan literasi sains siswa dianalisis berdasarkan normalized gain atau sering disebut gain score ternormalisasi. Besarnya gain score dianalisis menggunakan rumus Hake.

Keterangan:

$$
\langle\mathrm{g}\rangle=\frac{\mathrm{S}_{\mathrm{f}}-\mathrm{S}_{\mathrm{i}}}{100-\mathrm{S}_{\mathrm{i}}}(1)
$$

$\langle\mathrm{g}\rangle \quad=$ gain yang dinormalisasi

$\mathrm{S}_{\mathrm{f}} \quad=$ skor post-test

$\mathrm{Si} \quad=$ skor pre-test

$100=$ skor maksimum

Hasil perhitungan gainscore tersebut kemudian dimaknai menggunakan acuan yang dikemukakan oleh Hake pada Tabel 3.

Tabel 3. Kriteria Tingkat Gain

\begin{tabular}{ll}
\hline$\langle\mathrm{g}\rangle$ & Kriteria Gain Score \\
\hline $\mathrm{g}>0,7$ & Tinggi \\
$0,3 \leq \mathrm{g}<$ & Sedang \\
0,7 & \\
$\mathrm{~g}<0,3$ & Rendah \\
\hline
\end{tabular}

Kriteria Ketuntasan Minimal (KKM) Satuan Pendidikan untuk mata pelajaran Kimia di Kelas X SMA Negeri 7 Palangka Raya adalah 65. Untuk mengetahui ketuntasan siswa maka dihitung nilai posttest masing-masing siswa kemudian dimaknai tingkat penguasaan siswa dengan menggunakan Tabel 4 dan Persamaan 2 dan 3.

Tabel 4. Klasifikasi Tingkat Penguasaan

\begin{tabular}{cccc}
\hline $\begin{array}{c}\text { KKM Satuan } \\
\text { Pendidikan }\end{array}$ & $\begin{array}{c}\text { Persentase } \\
\text { Penguasaan }\end{array}$ & $\begin{array}{c}\text { Nilai } \\
\text { Huruf }\end{array}$ & Predikat \\
\hline & $89<\mathrm{A} \leq 100$ & $\mathrm{~A}$ & Sangat Baik \\
65 & $77<\mathrm{B} \leq 89$ & $\mathrm{~B}$ & Baik \\
& $65 \leq \mathrm{C} \leq 77$ & $\mathrm{C}$ & Cukup \\
& $<65$ & $\mathrm{D}$ & Kurang \\
\hline
\end{tabular}

(Diadaptasi dari SMA Negeri 7 Palangka Raya, 2017)

Suatu indikator dikatakan tuntas apabila $\geq 75 \%$ siswa mencapai ketuntasan indikator (BSNP, 2007).

$$
\begin{aligned}
& \mathrm{K} \text { individual }=\frac{\sum \text { skor yang diperoleh siswa }}{\sum \text { skor maksimum }} \times 100 \% \\
& \mathrm{~K} \text { klasikal }=\frac{\text { jumlah siswa yang tuntas }}{\text { jumlah seluruh siswa }} \times 100 \% \ldots \ldots \ldots
\end{aligned}
$$

Penguasaan konsep siswa dikatakan tuntas belajarnya jika secara individu maupun klasikal kelas memenuhi Kriteria Ketuntasan Minimal (KKM) pada mata 
pelajaran kimia. KKM Kimia kelas X MIPA di SMA Negeri 7 Palangka Raya sebesar 65.

\section{Hasil Penelitian Dan Pembahasan}

Hasil analisis kemampuan literasi sains siswa setelah penerapan model inkuiri terbimbing (guided inquiry) secara keseluruhan ditunjukkan pada Gambar 1.



Gambar 1. Analisis Pencapaian Literasi Sains Berdasarkan Jumlah Siswa

Gambar 1 menunjukkan bahwa hasil tes kemampuan literasi sains siswa sebanyak 5 orang siswa dalam kategori sangat baik, 18 orang siswa dalam kategori yang baik, dan masing-masing 2orang siswa dalam kategori yang cukup dan kurang. Sehingga dapat disimpulkan ketercapaian literasi sains siswa secara keseluruhan berkategori baik.

Hasil di atas didukung dengan data peningkatan literasi sains siswa dengan gain score 0,84 kategori tinggi, dengan sebaran kategori seperti disajikan pada Gambar 2 berikut.

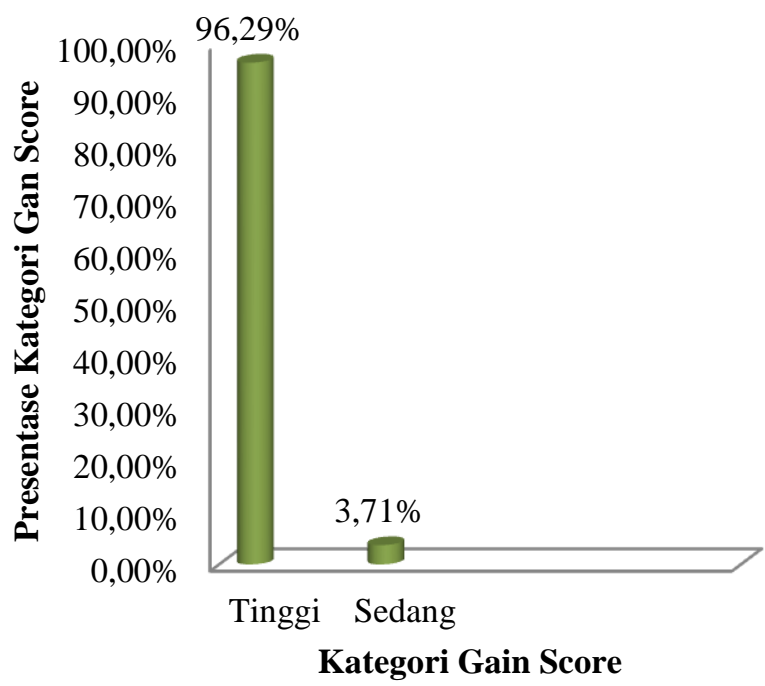

Gambar 2. Presentase Kriteria Gain Score Literasi Sains Siswa 
Gambar 2 menerangkan bahwa ada 96,29\% siswa yang memiliki gain score dengan kategori tinggi dan $3,71 \%$ siswa yang memiliki gain score dengan kategori sedang dan hal ini menunjukkan ada peningkatan literasi sains siswa dalam pembelajaran berbasis guided inquiry.

Hasil di atas mendukung penguasaan konsep siswa yang mana berdasarkan Tabel 4 di atas, pada saat posttest jumlah siswa yang tuntas melebihi $75 \%$ baik secara klasikal kelas maupun secara individu, yang disajikan pada Gambar 3.

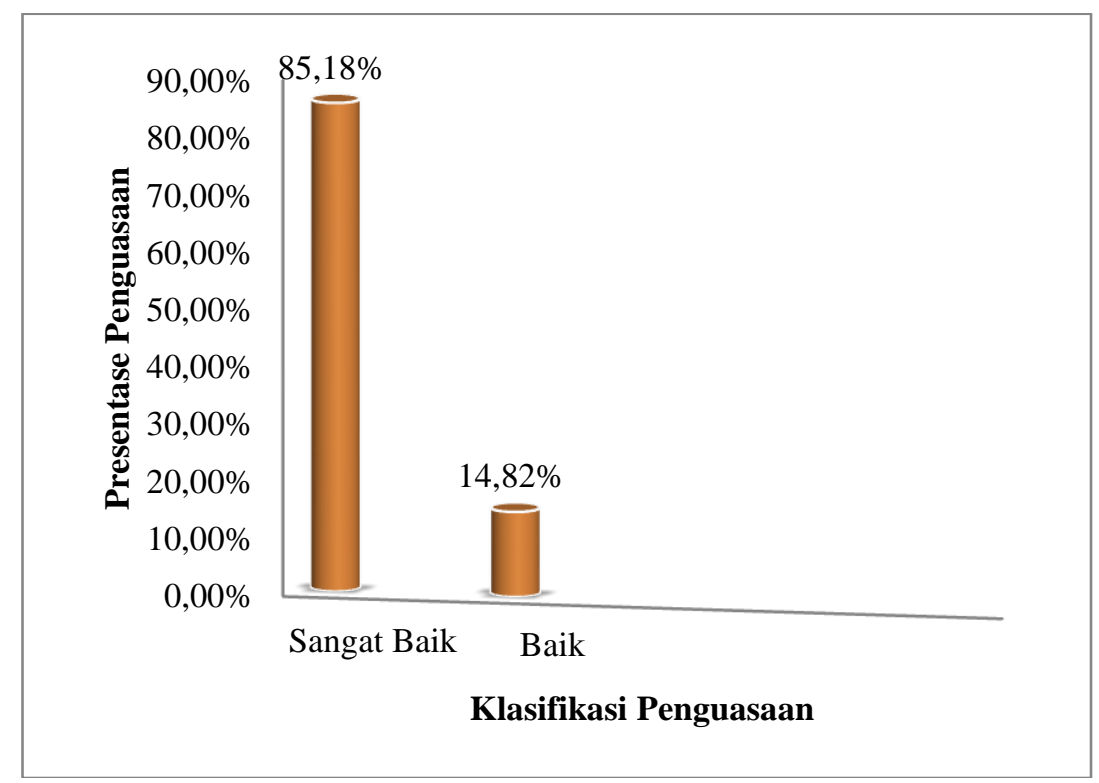

Gambar 3. Klasifikasi Tingkat Penguasaan Konsep Siswa

Nilai rata-rata posttest siswa pada pembelajaran berbasis guided inquiry sebesar 92,69 telah mencapai di atas KKM yang ditetapkan oleh sekolah sebesar 65 dan melampaui batas $75 \%$ yang ditetapkan BSNP. Gambar 3 menjelaskan juga bahwa jumlah siswa yang tuntas mencapai $100 \%$ dari jumlah siswa yang terlibat dalam pembelajaran berbasis guided inquiry pada pokok bahasan larutan elektrolit dan nonelektrolit. Hal ini menunjukkan pembelajaran berbasis guided inquiry dapat membantu siswa mencapai nilai kimia dan meningkatkan kemampuan literasi sains siswa.

Peningkatan literasi sains siswa yang masuk dalam kategori tinggi serta lebih efektif sangat dipengaruhi oleh model pembelajaran yang melekat pada proses belajar mengajar, yaitu model pembelajaran guided inquiry. Proses pembelajaran guided inquiry mengajarkan siswa untuk berpartisipasi aktif dalam rangka menemukan pengetahuan baru secara individu dengan bimbingan dan motivasi dari guru. Dalam pembelajaran ini siswa banyak melakukan investigasi menggunakan berbagai sumber belajar, baik melalui eksperimen, merancang percobaan dan mengumpulkan data dalam kegiatan percobaan sehingga akan menstimulasi kemampuan literasi sains siswa yaitu kemampuan mengidentifikasi, menganalisis sampai menarik kesimpulan dari sebuah fenomena yang ia temui sehingga siswa akan memahami pengaruh sains terhadap perkembangan teknologi dan implikasinya bagi kehidupan.

Hasil yang didapatkan tidak terlepas dari proses dan sintaks pembelajaran dalam guided inquiry tersebut. Pada pembelajaran berbasis guided inquiry siswa 
dibimbing untuk menemukan konsep sendiri dan dalam proses pembelajaran terlihat sebagian besar siswa mulai tampak antusias dan mulai tertarik mengeluarkan pendapat karena rasa penasaran yang dimilikinya atas pertanyaanpertanyaan yang diberikan oleh guru pada tahap kontak dan kuriositi. Pada tahap elaborasi siswa lebih aktif, terutama pada saat praktikum merangkai alat uji praktikum kimia sederhana dan merangkai baterai buah dari jeruk, terlihat bahwa siswa tertarik untuk terus mencoba menguji sifat dari beberapa larutan yang dilarutkan dalam air serta merangkai susunan buah menjadi rangkaian yang dapat menghantarkan listrik. Selama proses pembelajaran, timbul beberapa pertanyaan yang diungkapkan secara lisan tentang penyebab suatu larutan dapat menghantarkan listrik. Contohnya, seperti gula dan garam, kedua jenis senyawa tersebut sama-sama berwujud padat sebelum dilarutkan dalam air. Tetapi garam dalam air dapat menghantarkan listrik. Dalam proses diskusi bersama teman, guru membimbing siswa untuk menghubungkan jenis ikatan dengan kemampuan suatu zat menghantarkan listrik serta menghubungkan dengan ciri-ciri daya hantar listrik pada larutan yang diuji, siswa mencari dari beberapa literatur dan kemudian mengkonfirmasikannya.

Meskipun menemukan beberapa kesulitan dalam terutama dalam merangkai baterai yang terbuat dari buah jeruk. Berdasarkan kegiatan tersebut terlihat bahwa rasa ingin tahu siswa semakin besar, tidak mudah menyerah, berpikir kritis dan menjadi lebih kreatif, sehingga pada tahap pengambilan keputusan siswa dapat mengambil keputusan yang benar atas pertanyaan jawaban di awal. Pada tahap berikutnya siswa sedikit demi sedikit mulai dapat menghubungkan materi dengan contoh aplikasi di dalam kehidupan sehari-hari dengan bimbingan dari guru. Dengan demikian siswa menjadi lebih bersemangat dan fokus dalam belajar yang mengakibatkan hasil belajarnya lebih baik Pembelajaran berbasis guided inquiry memberikan peningkatan hasil belajar yang lebih baik, siswa lebih berpartisipasi aktif dalam pembelajaran dan rasa ingin tahu siswa bertambah karena siswa diberikan kesempatan untuk untuk mengenali, menemukan dan mencari tahu berbagai aplikasi sains dalam kehidupan sehari-hari yang berhubungan dengan materi larutan elektrolit dan non elektrolit, sehingga siswa mulai menyadari bahwa banyak sekali contoh aplikasi tersebut yang dekat dengan kehidupannya. Sehingga dalam proses pembelajaran selain pemahaman konsep siswa tentang larutan elektrolit dan nonelektrolit menjadi baik, literasi sains siswa juga meningkat. Hal ini membuktikan pembelajaran berbasis guided inquiry efektif meningkatkan kemampuan literasi sains siswa. Peran guru dalam guide inquiry, tidak berpengaruh besar dalam proses pembelajaran, guru hanya berfungsi mengarahkan siswa sehingga tidak terjadi kesalahan dalam penemuan konsep pembelajaran.

Pada saat pembelajaran siswa saling memberikan komentar atas jawaban yang disampaikan temannya dan mereka semakin aktif bertanya maupun mengemukakan pendapatnya terhadap suatu sains yang ada di dalam kehidupan sehari-hari sehingga membuat mereka menjadi lebih senang dan bersemangat yang terlihat dari respon yang diberikan. Dengan demikian pembelajaran yang terjadi lebih berpusat ke siswa dan terjadi pembelajaran yang lebih dinamis, siswa saling mengemukakan pendapat dan menanggapi pendapat temannya, sehingga suasana belajar menjadi lebih hidup. Selain itu, aspek literasi sains berupa kompetensi juga dapat dilatihkan di diri siswa, siswa mulai dapat merancang 
percobaan, menjelaskan fenomena yang terjadi secara ilmiah, dan menginterpretasikan data serta menganalisis data yang diperoleh dalam proses diskusi dan presentasi kelas. Hal ini didukung dengan wawancara tidak terstruktur terhadap siswa terhadap proses pembelajaran, $100 \%$ siswa yang mengikuti pembelajaran menyatakan pembelajaran seperti ini sangat baru bagi mereka, terutama dalam hal merancang percobaan dan menginterpretasikan data. Siswa sangat merasa bersemangat dalam belajar karena dihadapkan dengan materi yang baru, melakukan percobaan dan membahas tentang pengaruh larutan atau minuman isotonik yang dikonsumsi bagi tubuh manusia. Karena pada saat percobaan telah diuji sifat daya hantar minuman isotonik tersebut, membuat siswa merasa sangat antusias terlebih pada saat merangkai baterai buah dari buah jeruk.

Menurut siswa konsep yang dipelajari sangat bermanfaat terutama karena konsep yang dipelajari berhubungan dengan kehidupan sehari-hari.

Hasil penelitian ini juga sejalan dengan yang hasil penelitian dilakukan Carlson (2008), Dewi, et al. (2013), dan El Islami, et al. (2016), guided inqury dapat meningkatkan penguasaan konsep dan kemampuan literasi sains siswa.

\section{Kesimpulan}

Pembelajaran berbasis guided inquiry lebih efektif dalam meningkatkan literasi sains siswa dengan gain score 0,84 kategori tinggi, dengan rata-rata nilai posttest siswa 92,69 dengan tingkat ketuntasan belajar siswa 100\%. Hasil penelitian disimpulkan bahwa setelah penerapan model pembelajaran berbasis guided inquiry efektif meningkatkan kemampuan literasi sains siswa dengan kategori tinggi.

\section{Daftar Pustaka}

Astuti, Tri. (2015). Manajemen Praktikum Pembelajaran IPA. Jurnal Manajer Pendidikan, Volume 9, Nomor 1, Maret 2015, hlm. 57-64. Online. https://media.neliti.com/.../270689-manajemen-praktikum-pembelajaran-ipaad25580... Diakses 2 April 2019

Carlson, J. L. (2008). Effect of Themebased, Guided Inquiry Instruction on Science Literacy in Ecology. Thesis. Michigan Technology University. Online. citeseerx.ist.psu.edu/viewdoc/download?doi=10.1.1... Diakses 2 April 2019

Dewi, N. L., Dantes, N. dan Sadia, I. W. (2013). Pengaruh Model Pembelaja-ran Inkuiri terbimbing Terhadap Sikap Ilmiah dan hasil Belajar IPA. Jurnal Program Pascasarjana Universitas Pendidikan Ganesha, Vol 3, No 1, Hal 1-10. Online. https://media.neliti.com/media/publications/119287-ID-none.pdf. Diakses 2 April 2019

El Islami, R. A. Z., Nahadi, N. dan Permanasari, A. (2016). Membangun Literasi Sains Siswa pada Konsep Asam Basa melalui Pembelajaran Inkuiri Terbimbing. Jurnal Penelitian dan Pembelajaran IPA, Vol 2, No 2,. Hal 110-120. Online. https://media.neliti.com/.../176921-ID-membangun-literasi-sains-siswa-padakons.pdf. Diakses 2 April 2019.

Hake, R.R., 1998,Interactive-engangement versus tradisional methods: A Sis-thousandstudent Survey of Mechanics Test Data for Introductory physics course, America:The American Journal of Physics Teacher.

Jack Holbrook \& Miia Rannikmae. (2009). The Meaning of Scientific Literacy. International Journal of Environmental \& Science Education. 
McConney, A., Oliver, M. C., Amanda, W. M., Schibeci, R. dan Maor, D. (2014). Inquiry, Engagement, and Literacy in Science: A Retrospective, Cross-National Analysis Using PISA 2006. Science Education, Vol 98, No 6, Hal 963- 980.

M. Pranjoto Utomo. (2011). Adaptasi Pelaksanaan Praktikum Kimia Negara OECD. Makalah Disampaikan pada Kegiatan PPM Unggulan Berjudul "Adaptasi Kurikulum Kimia SMA Bertaraf Internasional terhadap Kurikulum dari Negara OECD" pada tanggal 4 Juni 2011, FMIPA UNY.

Murniningsih, I. M., Masykuri, M., dan Mulyani, B. (2016). Penerapan Model Pembelajaran Inkuiri Terbimbing untuk Meningkatkan Sikap Ilmiah dan Prestasi Belajar Kimia Siswa. Jurnal Inovasi Pendidikan IPA, Vol 2, No 2, Hal 177- 189.

Napsin Palisoa. (2008). Strategi Advance Organizer dalam Pembelajaran Kimia. (Online).(http://isjd.pdii.lipi.go.id/index.php/Search.html?act=tampil\&id=73 15\&idc $=32$, diunduh 23 April 2019).

OECD. (2013). Pisa 2015 Draft Science Framework March 2013. Diakses pada www.oecd.org.

OECD. (2014). Pisa 2012 Result in Focus What 15-Year-Olds Know and What They Can Do With What They Know. Paris: OECD Publishing

OECD. (2016). Assesing Scientific, Reading and Mathematical Literacy A Framework for PISA 2015. Paris: OECD Publising.

Peter Nentwig and David Waddington. (2005). Chemie Im Context-From Situated Learning In Relevant Contexts to a Systematic Development of Basic Chemical Concepts. Making It Relevant: Context Based Learning of Science. Waxmann: Germany.

Pusat Kurikulum. (2003). Standar Kompetensi Mata Pelajaran Kimia SMA dan MA. Jakarta: Balitbang Depdiknas.

Pusat Penilaian Pendidikan Balitbang. (2011). Survei Internasional PISA. Jakarta: Kementrian Pendidikan dan Kebudayaan.

Puspitasari, A. D. (2015). Efektitas Pembelajaran Berbasis Guided Inquiry untuk Meningkatkan Literasi Sains Siswa. Jurnal Omega, Vol 1, No 2, Hal 1-5. Online. http:// omega.uhamka.ac.id/index.php/omega/article/download/23/37. Diakses 10 April 2019.

Sanjaya, W. (2012). Strategi Pembelajaran Berorientasi Standar Proses Pendidikan. Jakarta: Kencana

Sujana, A. (2014). Pendidikan IPA Teori dan Praktik. Bandung: Rizqi Press

Suyanti, R. D. (2010). Mendesains Model Pembelajaran Kimia. Yogyakarta: Graha Ilmu. Shwartz, W., Ben-Zvi, R., dan Hofstein, A., 2006, The Importance of Involving High School Chemistry Teacher in the Process of Defining The Operational Meaning of 'Chemistry Literacy', International Journal of Science Education, Vol 27, No 3, Hal 323-344

Trianto. (2007). Model Pembelajaran Terpadu dalam Teori dan Praktek. Jakarta: Prestasi Pustaka. 